\title{
J
}

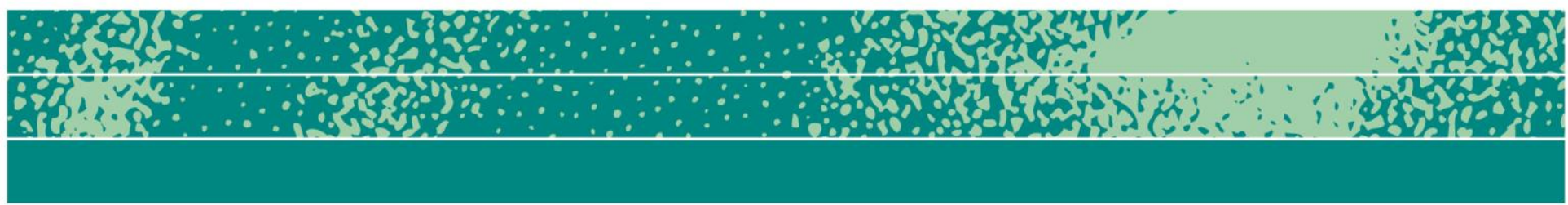

Just Be Active! A Response

\section{Two Reflections on the Symbolic Position of Business Anthropology}

\author{
Christina Wasson
}

These comments offer some brief reflections on the symbolic position of business anthropology within mainstream anthropology. I wish to engage with $J B A$ Editor Moeran's Letter from the Editor, specifically his reminder to mainstream colleagues that business or capitalism plays a central role in just about any anthropological research topic (Moeran 2014:116-117). Why is it necessary to make this argument? What does it say about attitudes toward business and capitalism among mainstream anthropologists? And how can these attitudes be contextualized and theorized?

Other scholars have already explored these questions from various vantage points. For instance, Baba has examined how the political and economic history of anthropology's development as a discipline led to boundary tensions between academics and practitioners (2009). Others have linked the stigmatization of applied work to the scandals of the 1970 s concerning anthropological participation in the Vietnam War and related conflicts (Nolan 2003:3; Rylko-Bauer et al. 2006:181). I will merely add two reflections that occurred to me as I read Moeran's comments.

My first reflection starts from the observation of a new wave of
Page 1 of 4

JBA 3(1): 11-14

Spring 2014

(C) The Author(s) 2014 ISSN 2245-4217

www.cbs.dk/jba 
scholarly interest in corporations among academic anthropologists. For instance, an interest group on corporations was constituted at the American Anthropological Association Meeting in 2013 (http://anthropologyofcorporations.wordpress.com/). And the 2013 Annual Review of Anthropology included an article on "Ethnographic Research on Modern Business Corporations" (Urban and Koh 2013). At the same time, it seems that many of the anthropologists who are developing this interest in business are not engaging much with the existing community of business anthropologists (which includes both academics and practitioners).

The unfolding dynamic between this new group of academic anthropologists and existing business anthropologists seems strikingly similar to the emergence of "public anthropology" fifteen years ago. Around the turn of the century, academics who were concerned about mainstream anthropology's "intellectual isolation and insulation from the world's problems" sought to create a new form of anthropology that would engage with matters of broad public concern (Borofsky 2000:9). They called this "public anthropology." Yet in conceptualizing a new form of anthropology, they ignored the existence of applied anthropology, whose practitioners had been engaging with matters of public concern for years (Rylko-Bauer 2000).

As public anthropology started to emerge, the applied anthropologist Merrill Singer argued that members of the former group seemed "to be unaware of the varied kinds of public interest work now being carried out by applied anthropologists" (2000:6). Historically, he pointed out, it would be "more accurate to include public anthropology as a subfield of applied anthropology," rather than heralding engagement with public issues as a novel development (Singer 2000:6). Singer expressed concern that a two-class system was being created.

So I wonder whether a similar dynamic of reinvention isn't happening with the study of corporations. For instance, the Annual Review of Anthropology could have solicited an article about corporations at any time over the last twenty years; there were plenty of scholars to write one. The fact that an article on this topic appeared in 2013, and that it was not written by senior business anthropologists, seems to signal a recent surge of interest among anthropologists who are not historically associated with business anthropology.

The apparent reiteration of this dynamic of reinvention leads me to my second reflection. Understanding the dynamic would seem to require critical analysis of the field of anthropology, including its political, economic and symbolic dimensions. Many disciplines include a symbolic opposition between theory and application. However, this opposition seems to be particularly marked in our discipline. Various contributing factors have been examined by other researchers, as noted above. I would like to suggest that another productive avenue for analysis might 
draw on Bourdieu's insights. Bourdieu reminds us to examine the social conditions of the possibility for the scholastic habitus (1990). It might be useful to investigate why academic anthropologists have been inculcated with a disposition that stigmatizes applied work. Bourdieu offers a starting point in noting that historically, academic scholarship emerged through a very particular cultural and economic arrangement: "the situation of skholè, of leisure, of which the school... is a particular form, as an institutionalized situation of studious leisure... The social conditions of possibility of the scholastic point of view and the unconscious dispositions, productive of unconscious theses, which are acquired through an academic or scholastic experience, [are] often inscribed in prolongation of an originary (bourgeois) experience of distance from the world and from the urgency of necessity" (Bourdieu 1990:381; cf. Baba 2000:31).

One could extend Bourdieu's historical analysis to an examination of the ways in which symbolic capital is currently constituted in academic anthropology. This would involve mapping the terrain of the discipline, which is far from being a uniform field in Bourdieu's sense. For instance, the "rules of the market" that assign symbolic value to particular activities vary considerably across anthropology departments. In particular, departments occupy various positions along a continuum that ranges from according high value to applied anthropology, on the one hand, to stigmatizing it, on the other. One could productively investigate the cultural logics that shape the assignment of symbolic capital in these different contexts, and how they link to the political economic circumstances in which departments are located, including various kinds of academic hierarchies.

It would also be interesting to continue to track the evolution of the two dynamics of reinvention that I have identified above. The term public anthropology seems to have become less contentious among applied anthropologists in recent years. Perhaps they have concluded that an inclusive strategy is more effective than an oppositional one. And in some ways it seems that applied work is becoming more accepted in academic anthropological circles, although there are still plenty of departments that stigmatize it. The new Executive Director of the AAA, a long-term applied anthropologist, is taking various steps to increase the symbolic capital of applied work. So we can hope that a similar process of increased inclusion may develop between the new wave of anthropologists interested in corporations and the existing community of business anthropologists.

\section{References}

Baba, Marietta L. 2000. 'Theories of Practice in Anthropology: A Critical 
Appraisal.' NAPA Bulletin 18:17-44.

Baba, Marietta L. 2009. 'Disciplinary-Professional Relations in an Era of Anthropological Engagement.' Human Organization 68(4):380-391.

Borofsky, Robert. 2000. 'Public Anthropology. Where To? What Next?' Anthropology News 41(5):9-10.

Bourdieu, Pierre. 1990. 'The Scholastic Point of View.' Cultural Anthropology 5(4):380-391.

Moeran, Brian. 2014. 'Just Be Active! Letter from Your Editor.' Journal of Business Anthropology 2(2):115-119.

Nolan, Riall W. 2003. 'Anthropology in Practice: Building a Career Outside the Academy.' Boulder: Lynne Rienner Publishers.

Rylko-Bauer, Barbara. 2000. 'Toward a More Inclusive Relevant Anthropology.' Society for Applied Anthropology Newsletter 11(2): 6-7.

Rylko-Bauer, Barbara, Singer, Merrill, and John Van Willigen. 2006.

'Reclaiming Applied Anthropology: Its Past, Present and Future.' American Anthropologist 108(1):178-190.

Singer, Merrill. 2000. 'Why I am Not a Public Anthropologist.'

Anthropology News 41(6):6-7.

Urban, Greg and Kyung-Nan Koh. 2013. 'Ethnographic Research on Modern Business Corporations.' Annual Review of Anthropology 42:139158.

Christina Wasson (Professor of Anthropology, University of North Texas) has played in the conjuncture between anthropology and business since 1990. Wasson formerly worked for E-Lab, a design firm that used anthropological research to develop new product ideas, and was a founding organizer of the Ethnographic Praxis in Industry Conference (EPIC). Her work is motivated by a passion to investigate three " $\mathrm{C}$ "s: communication, collaboration, and community-building. Wasson may be reached atcwasson@unt.edu. 